must be available in London for interview in March 1954; age 23-32 ; tenure, 12-21 months ; applications by December 15. Home Civil Service : five fellowships to permanent members in the higher ranks of the Civil Service in Great Britain, three for the administrative grades and two for the scientific and professional grades; age, less than 40 ; tenure, 6-12 months; applications by December 31. Dominion Civil Service : five fellowships to Civil servants in the Governments of Australia and New Zealand; age less than 40 ; tenure, $9-15$ months ; applications by November 1. Colonial Civil Service: two Fellowships to Civil servants in the Governments of British Colonies, Protectorates and Trust Territories; age, less than 40 ; tenure, 6-12 months; applications by November 16. Journalism : three fellowships to journalists, practising in the United Kingdom and engaged on the opinion-making or broadly editorial side of their profession; age, 23-35; tenure, 9-15 months ; applications by December 31. American Studies : four Fellowships to faculty members appointed to or holding posts in American studies in universities in the United Kingdom; candidates to be nominated by their universities; tenure, 4-12 months (these Fellowships are not limited by previous study in the United States). Application forms and further details of these Fellowships can be obtained through British universities or through Government departments, or from the Warden, Harkness House, 35 Portman Square, London, W.1.

\section{Controlled Leaf Morphogenesis}

By growing plants of Marsilea in aseptic culture media of known composition, A. Allsopp (Ann. Bot., N.S., 17, 65, 37 ; 1953) has shown that the leaf shape can be controlled. In plants with the characteristic tetrafid adult leaves, reversion to simple bifid or awl-shaped juvenile leaves was obtained by depriving the cultures of either sugar or mineral nutrients. There was also a concomitant reduction of the solenostele to a protostele. Comparable results were obtained by using the excised apices of rhizomes or their lateral branches. These results are of particular interest in relation to the general problem of heteroblastic leaf development-a phenomenon originally attributed by Goebel to nutritional factors but variously ascribed to other causes by different investigators. The main body of evidence supports Goebel's view ; but the precise relation of nutrition to the regulated ontogenetic pattern of leaf development has never been elucidated. In a discussion of this problem, reference is made to the changing dimensions of the shoot apical meristem during the normal ontogenetio enlargement and under 'starvation' conditions. In most cases of heteroblastic development it is unnecessary to seek exp? mations in terms of special growth substances, physiological ageing, etc. In the individual plant the changing size of the apex under the influence of nutritional factors would seem to afford an adequate explanation.

\section{The Luffo Plant and its Uses}

ThE loofah of commerce, also known as the 'Luffa sponge', 'dishcloth' or 'dishrag gourd', 'snake gourd' and 'vegetable sponge', is the cleaned, dried inner fibrous tissue of the fruit or gourd of Luffa spp., which grow readily in most warm countries. It is a climbing annual plant, and has been grown in Japan from olden times. The plant and fruits resemble cucumbers; but the fruits are fatter and hang heavily on the vines, while the stems are more.woody and stronger. In Japan, the plant blooms during June-July, and the flowers last well into the autumn. The two most common species are Luffa cylindrica, to which belong the varieties cultivated in Japan for loofah production, and $L$. acutangula. Both species produce good fibre; but with $L$. cylindrica the fruits are bigger and more cylindrical in shape, and the fibres are of better quality. The best type of loofah for the commercial market is the one produced in Japan, where the soil and climate have proved well suited to their cultivation. An account of the loofah industry in Japan has been given by J. S. Ingram in Colonial Plant and Animal Products (3, No. 2). The cultivation and possibilities of the plant in Colonial territories is also described.

\section{Bird Preservation}

IN 1950 a conference was held in Paris to discuss the revision of the international convention for the protection of birds useful to agriculture, which had been signed in 1902. The conference was attended by delegates from Austria, Belgium, Denmark, France, Greece, Netherlands, Portugal, Spain, Sweden, Switzerland, Turkey and the United Kingdom and, on behalf of their Governments, a new draft convention was signed ad referendum by all delegates. The full text of the convention is set out in the sixth bulletin of the International Committee for Bird Preservation, which has been prepared with sections in Jinglish, German and Spanish and may be obtained from the British Museum (Natural History), Cromwell Road, London, S.W.7. Besides the usual reports on bird protection in various countries, the bulletin also reviews the work of the International Wild Fowl Research Institute and gives full details of the legislation which has been adopted by member countries for the better preservation of wild fowl.

\section{Philosophy for Management}

A VALUABLE guide for members of its supervisory staff has recently been issued by the Triplex Safety Glass Co., Ltd. The supervisory staff is taken to include the directors, senior staff and foremen; and, in a foreword, the chairman and managing director, Sir Graham Cunningham, suggests that the booklet will help them to become clear about the policy of the Company and about the human relationships involved in it. The booklet includes a chart showing the organization of the Triplex Group and short explanatory statements on such topics as the function of the board of directors, research and development, the meaning of profit, the reasons for the use of specialist departments, the role of the trade unions, the structure of wages, the value of suggestion schemes, accident prevention and personnel services. The booklet is written in a succinct and admirable manner, and the ideas contained in it might well be copied for use in other firms.

\section{Endeavour}

IN the eleven years since it was first published by Imperial Chemical Industries, Ltd., the quality of the contributions to Endeavour has been at a consistently high level. It is doubtful whether any previous issue, however, could equal the quality of the articles appearing in the July issue of this journal. W. B. Alexander, for example, has written an admirable article on ornithological illustration which is sup. 